\title{
Late Permian plume-related magmatism and tectonothermal events in the Kontum Massif, central Vietnam
}

\author{
Masaaki OWADA*, Yasuhito OsANAI ${ }^{* *}$, Nobuhiko NAKANO ${ }^{* *}$, Tatsuro ADACHI ${ }^{* *}$, \\ Ippei KITANO $^{* * *}$, Tran Van TRI ${ }^{\dagger}$ and Hiroo KAGAMI ${ }^{*}$ \\ *Department of Earth Sciences, Yamaguchi University, Yamaguchi 753-8512, Japan \\ ${ }^{* *}$ Division of Earth Sciences, Faculty of Social and Cultural Studies, Kyushu University, Fukuoka 819-0395, Japan \\ ${ }^{* * *}$ Graduate School of Integrated Sciences for Global Society, Kyushu University, Fukuoka 819-0395, Japan \\ ${ }^{\dagger}$ General Department of Geology and Minerals of Vietnam, Hanoi, Vietnam \\ \$2053-16 Oaza Ohmachi, Omachi, Nagano 398-0002, Japan
}

\begin{abstract}
The Kontum Massif is situated in the southern part of Trans Vietnam Orogenic Belt (TVOB), central Vietnam, and contains various types of magmatic and metamorphic rocks, the latter including both ultrahigh-pressure and ultrahigh-temperature units. While geochronological data indicate the existence of two main tectonothermal events at 480-420 Ma and 270-240 Ma, the most intense metamorphic and magmatic activity occurred between the Late Permian and Early Triassic due to continental collision between the South China and Indochina cratons. In this study, U-Pb LA-ICP-MS geochronological analyses of zircon obtained from two samples of metagabbro and one sample of charnockite from the massif yielded a magmatic age range of 260-250 Ma for all three samples and an inherited age of $\sim 1400$ Ma for the charnockite. These magmatic ages overlap with those documented for peak metamorphism in the Kontum Massif. When combined with $\mathrm{Nd}$ isotopic data for granitic rocks and pelitic gneisses from the region, these data suggest that the massif may have been derived from reworked continental crust. Geochemical characteristics of metagabbros from the massif reveal that the parental basaltic magma can be correlated with the Song Da igneous suite situated in the northern part of the TVOB, and was assimilated by crustal materials. The Song Da igneous suite is a member of the Emeishan large igneous province and resulted from Late Permian mantle plume activity. We conclude that the plume-related magma intruded into the deeper part of Kontum Massif and induced ultrahigh-temperature metamorphism of the lower crust by acting as a heat source.
\end{abstract}

Keywords: Metagabbro, Mantle plume, U-Pb zircon dating, Late Permian, Kontum Massif

\section{INTRODUCTION}

The collision and accretion of micro-continents plays an important role in large-scale continental growth throughout geological time. Ultrahigh-pressure (UHP) and/or ultrahigh-temperature (UHT) metamorphic rocks, together with syn- to post-collisional igneous rocks, are locally exposed in several collision zones in Asia (Okay et al., 1989; Ree et al., 1996; Zhang et al., 1996; Osanai et al., 2004; Oh et al., 2005; Osanai et al., 2008; Nakano et al., 2008, 2010). Late Permian to Early Triassic continental growth in Asia can be accounted for by collage tectonics, exemplified by events such as the collisions between the South

doi:10.2465/jmps.151019b

M. Owada, owada@sci.yamaguchi-u.ac.jp Corresponding author
China and Indochina cratons, and the North China and South China cratons (Metcalfe, 1999; Ishiwatari and Tsujimori, 2003). At around this time, the plume-related Emeishan flood basalts were erupted over a large region of southwest China, forming a large igneous province (the Emeishan LIP) (Chung and Jahn, 1995; Xu et al., 2001; Xiao et al., 2004; Ali et al., 2005).

Various metamorphic and igneous rocks are exposed over large regions of north and central Vietnam, with the former, including UHP and UHT lithologies (Figs. 1a and 1b). Both of these metamorphic rock types experienced a similar clockwise $P-T$ evolution during the Late Permian and Early Triassic periods (270-240 Ma: Osanai et al., 2004; Nakano et al., 2004, 2007a, 2007b, 2008; Osanai et al., 2008; Nakano et al., 2009, 2010). This led Osanai et al. (2008) to propose the name 'Trans Vietnam Oro- 


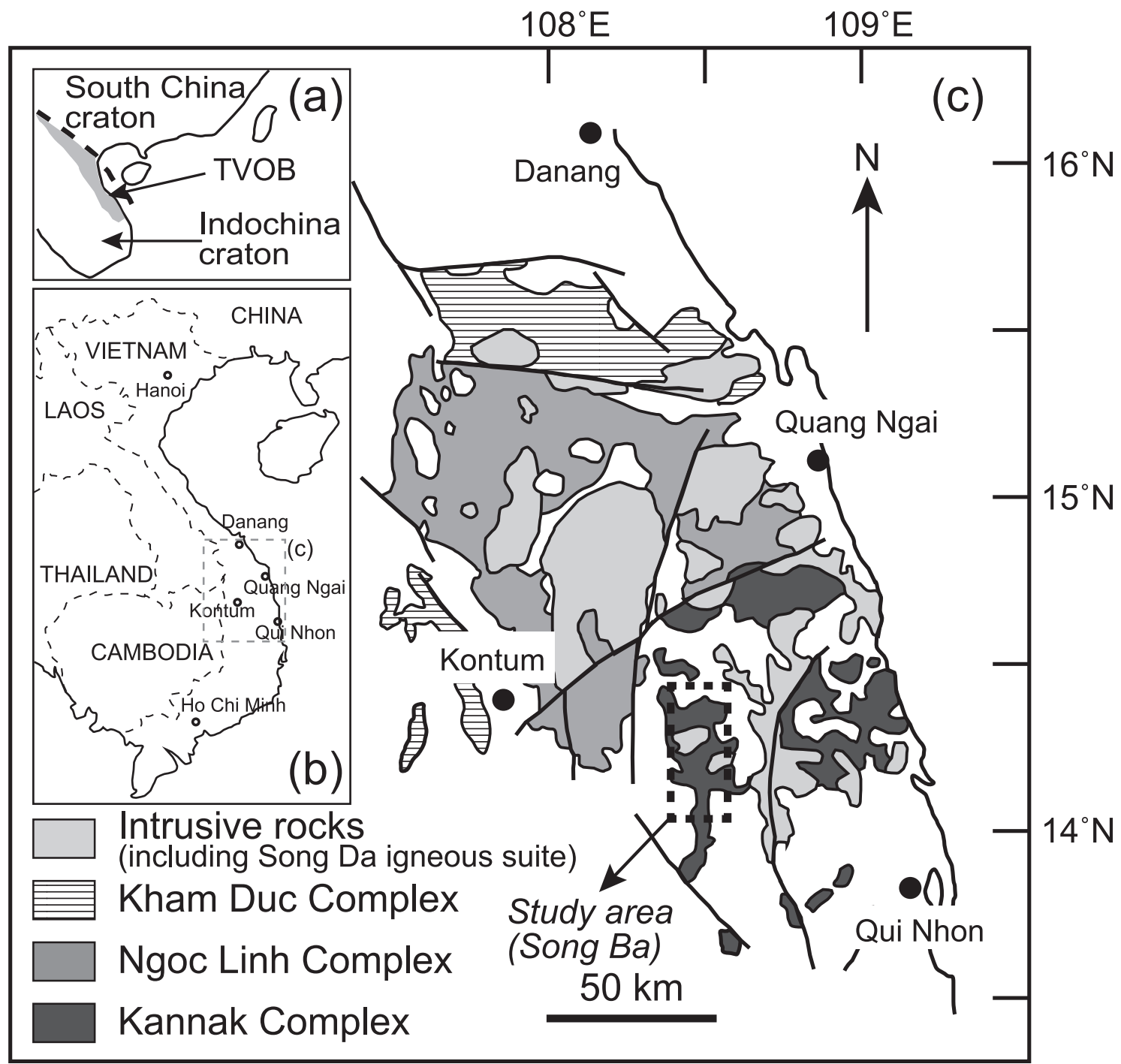

Figure 1. (a) The distribution of South China and Indochina cratons within the Trans Vietnam Orogenic Belt (TVOB) (after Osanai et al., 2008). (b) Locations of the Truong Son Belt (TB) and Kontum Massif (KM) in Vietnam, both of which form part of the TVOB. (c) Geological sketch map of the Kontum Massif, central Vietnam (after United Nations, 1990). The Kontum Massif can be divided into three metamorphic terranes: the Kannak, Ngoc Linh, and Kham Duc Complexes. Dashed square shows the location of the study area along the Ba River (Song Ba). Color version is available online from http://doi.org/10.2465/jmps.151019b.

genic Belt' (TVOB) for the region containing metamorphic and igneous rocks of this age (Fig. 1), which was interpreted to have formed due to collision between the South China and the Indochina cratons. In addition, the Late Permian plume-related Song Da igneous suite (Fig. 1c), a member of the Emeishan LIP (Hanski et al., 2004), is exposed in the northern part of the TVOB.

The Kontum Massif, central Vietnam, is located in the southern part of the TVOB and is thought to be a core complex of the Indochina craton (e.g., Hutchison, 1989). Geochronological studies have revealed that its metamorphic components experienced a complex history from the Middle Proterozoic to the Phanerozoic (Tran Ngoc Nam et al., 2001; Nakano et al., 2013), although major tectono- thermal events occurred during the Ordovician-Silurian and the Late Permian-Early Triassic (Carter et al., 2001; Nagy et al., 2001; Tran Ngoc Nam et al., 2001; Maluski et al., 2005; Roger et al., 2007; Lepvrier et al., 2008; Usuki et al., 2009; Nakano et al., 2013) (Fig. 2). According to Nakano et al. (2013), the Ordovician-Silurian thermal event occurred in an active continental margin tectonic setting, whereas the Late Permian-Early Triassic event was associated with UHP/UHT metamorphism and records the formation of deep-seated continental crust within the TVOB collision zone.

Elucidating the petrogenetic processes by which such extreme metamorphic and magmatic processes occur in collision zones provides valuable information regarding 


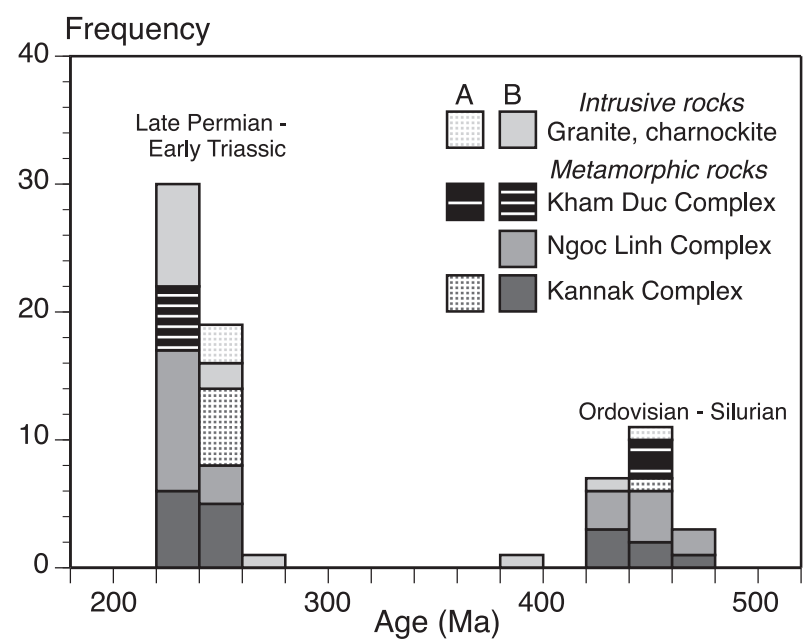

Figure 2. Summary of previously reported ages for metamorphic and intrusive igneous rocks from the Kontum Massif. (A) zircon $\mathrm{U}-\mathrm{Pb}$ isotopic age. (B) monazite $\mathrm{Th}-\mathrm{U}-\mathrm{Pb}$ chemical age. Data sources comprise Carter et al. (2001), Nagy et al. (2001), Tran Ngoc Nam et al. (2001), Owada et al. (2006), Roger et al. (2007), Usuki et al. (2009), and Nakano et al. (2013). Color version is available online from http://doi.org/10.2465/jmps.151019b.

the evolution of deep-seated continental crust (e.g., Condie, 1997). The Kontum Massif has a prolonged geological history and contains Late Permian UHT metamorphic rocks and syn-kinematic metamorphosed gabbro; hereafter, termed metagabbro (Nakano et al., 2004; Osanai et al., 2004; Owada et al., 2006, 2007; Nakano et al., 2007a). The mechanisms by which deep-seated continental crust formed within the TVOB collision zone are still unclear, although investigating the petrogenetic relationships between UHT metamorphism and the emplacement of extremely hot magmas could provide important insight into this issue (Osanai et al., 2008). As such, we have performed geochronological and geochemical investigations of metagabbros and related granitic intrusions from the Kontum Massif in order to 1) unravel its complex tectonothermal history, 2) constrain the age of mantle-derived magmatism with respect to UHT metamorphism and investigate potential petrogenetic links between the two, and 3) elucidate the magmatic processes involved with the formation of metagabbro in the region by comparing its geochemical features to those of the plume-related Song Da igneous suite from the northern part of the TVOB.

\section{GENERAL GEOLOGY OF THE KONTUM MASSIF}

The Kontum Massif is comprised of three distinct tectonostratigraphic terranes: the northwestern Kham Duc Complex, the central Ngoc Linh Complex, and the southeastern Kannak Complex (Tran Quoc Hai, 1986) (Fig. 1c).
The Kham Duc Complex is composed of low- to mediumtemperature and relatively high-pressure kyanite-bearing metamorphic rocks (Nakano et al., 2007a, 2007b), whereas the Ngoc Linh and Kannak Complexes contain hightemperature (HT) to UHT granulite that reached peak metamorphic $P-T$ conditions of $1.2 \mathrm{GPa}$ and $1050^{\circ} \mathrm{C}$ (Nakano et al., 2004; Osanai et al., 2004, 2008). Some of the UHT mafic granulites from the Ngoc Linh Complex record petrological evidence of an earlier eclogite-facies metamorphism (Nakano et al., 2004), and low-grade metamorphic rocks that may belong to the Kham Duc Complex are exposed in the southern part of the Kannak Complex (Fig. 1). Parts of these complexes are suggested to have experienced extreme metamorphism in a deep-crustal environment due to continental collision (Osanai et al., 2004; Nakano et al., 2004, 2007a, 2007b; Osanai et al., 2008).

Intrusive igneous rocks exposed in the Kannak Complex occur as stocks and lenses within granulite-facies metamorphic lithologies. Magmatic rocks of granitic composition are divided into two types: garnet-bearing granite and orthopyroxene-bearing granite (charnockite). The garnet-bearing granite locally shows a migmatitic structure with pelitic gneisses occurring as paleosome layers. Metagabbro occurs as stocks, lenses, or enclaves in the granitic rocks (Fig. 3a), and has dark, millimeterscale, and fine-grained chilled margins along contacts with the host granitic rocks (Fig. 3a). These relationships show that the granitic rocks and metagabbros were intruded coevally (Owada et al., 2006, 2007).

\section{PETROGRAPHY OF CHARNOCKITE AND METAGABBRO}

Charnockite in the Kannak Complex is composed mainly of plagioclase, quartz, $\mathrm{K}$-feldspar, orthopyroxene, and biotite, alongside small amounts of hornblende and clinopyroxene. Apatite, zircon, and opaque minerals occur as accessory phases. Felsic minerals are commonly larger than $5 \mathrm{~mm}$ in size, although mafic minerals orthopyroxene and biotite are 2-5 mm (Fig. 3b). Biotite flakes locally surround orthopyroxene grains.

Metagabbro in the Kannak Complex consists mainly of orthopyroxene, clinopyroxene, and plagioclase, with trace amounts of hornblende and biotite. Most examples exhibit a granoblastic texture (Figs. 3c and 3d). Apatite, opaque minerals, and zircon occur as accessory phases. Orthopyroxene locally includes euhedral to subhedral plagioclase (Fig. 3c), and plagioclase grains in the matrix locally include rounded quartz grains (Fig. 3d). Rare biotite grains define a weak foliation. Some of the metagabbros include large plagioclase grains mantled by aggregations of fine-grained mafic minerals (mainly pyroxenes). 


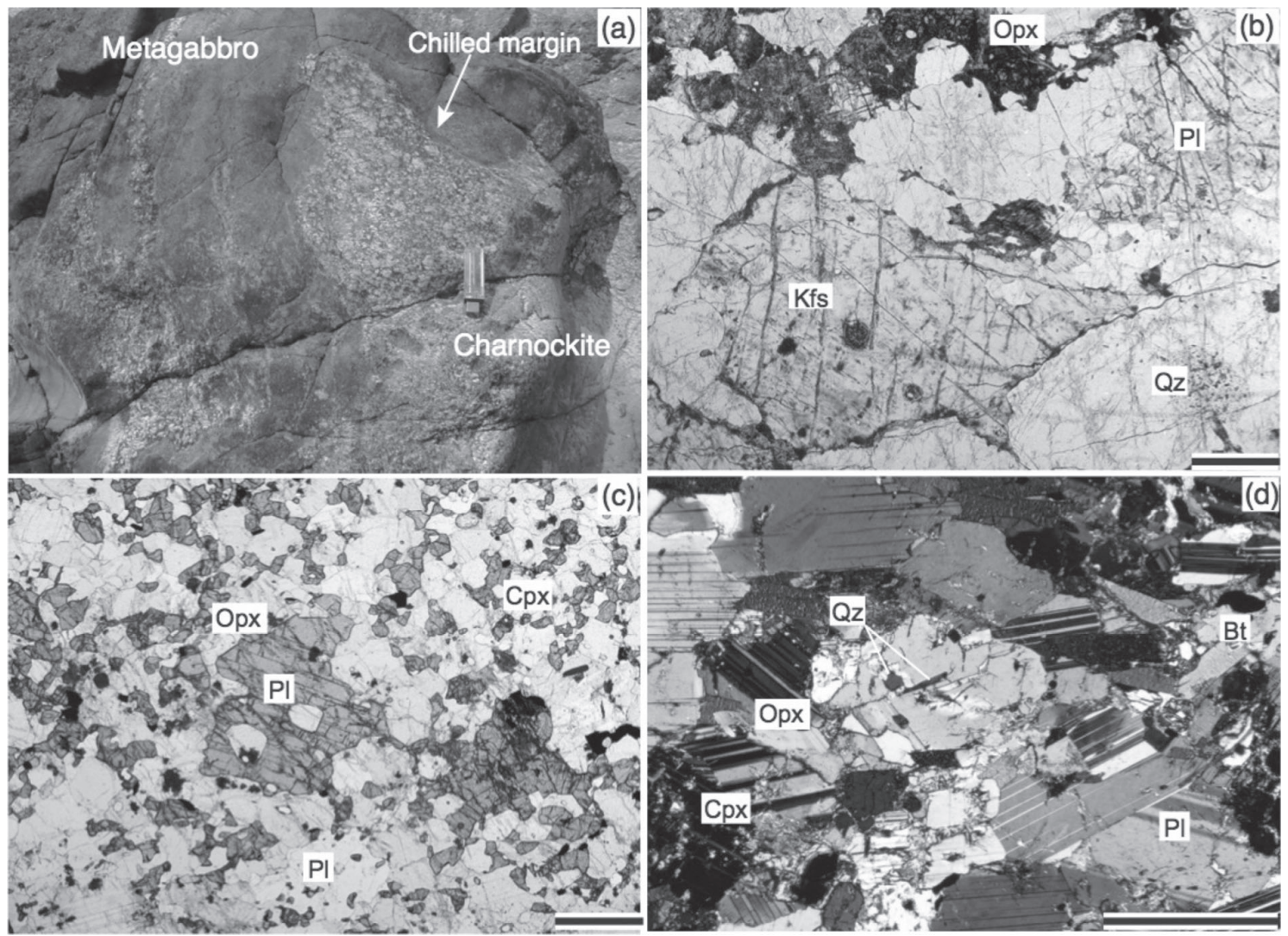

Figure 3. Field occurrence and photomicrographs of metagabbro and charnockite from the Song Ba area of the Kannak Complex. (a) Metagabbro is included as enclaves in charnockite and has fine-grained, dark-colored chilled margins (arrow) along its contact with the host, indicating that both lithologies intruded into the crust coevally. (b) Charnockite (sample 00041905B) is composed mainly of quartz, Kfeldspar, and plagioclase, with small amounts of orthopyroxene and biotite. (c) Metagabbro (sample 00042001C1) consists mainly of two pyroxenes and plagioclase, with minor amounts of biotite, and shows a granoblastic texture. The studied sample locally contains large orthopyroxene grains that include euhedral to subhedral plagioclase. (d) Metagabbro (sample 00041903B) has a mineral assemblage similar to sample 00042001C1, though locally contains quartz. All scale bars are $1 \mathrm{~mm}$ in length. Opx, orthopyroxene; Cpx, clinopyroxene; $\mathrm{Bt}$, biotite; Pl, plagioclase; Qz, quartz; Kfs, K-feldspar. Color version is available online from http://doi.org/10.2465/jmps.151019b.

This texture is similar to that commonly observed during magma mingling (Hibbard, 1995). Overall, these mineral assemblages and textural relations imply that both rock types underwent granulite-facies metamorphism following their emplacement.

\section{U-Pb DATING OF ZIRCON}

$\mathrm{U}-\mathrm{Pb}$ dating of zircon obtained from two samples of metagabbro and a charnockite was performed on a laser-ablation (LA) inductively coupled plasma mass spectrometer (ICP-MS) housed at the Graduate School of Integrated Sciences for Global Society, Kyushu University. The analytical procedure utilized has been described in detail by Adachi et al. (2012) and Nakano et al. (2014). Separated zircons were mounted in epoxy resin and polished. Internal textures and mineral inclusions were observed using a scanning electron microscope (JEOL JED2140 JSM-5301S) equipped with a cathodolumines- cence imaging system at Kyushu University. For U-Pb geochronology, concentrations of the isotopes ${ }^{202} \mathrm{Hg}$, ${ }^{204} \mathrm{~Pb},{ }^{206} \mathrm{~Pb},{ }^{207} \mathrm{~Pb},{ }^{208} \mathrm{~Pb},{ }^{232} \mathrm{Th}$, and ${ }^{238} \mathrm{U}$ were monitored during all analyses, with ablations performed using laser diameters of 30 to $40 \mu \mathrm{m}$. No reliable concentrations of ${ }^{204} \mathrm{~Pb}$ were obtained from any analyzed grains. Integrated isotopic ratios were corrected against the Temora zircon standard, which has a ${ }^{206} \mathrm{~Pb} /{ }^{238} \mathrm{U}$ age of 417 Ma (Black et al., 2003), and the NIST SRM-611 glass standard was used to calculate $\mathrm{Th} / \mathrm{U}$ ratios. All zircon data reductions and calculations were processed with GLITTER (Griffin et al., 2008) using the analytical and calculation protocols for time-resolved analysis described by Jackson et al. (2004). The software Isoplot/Ex 3.7 (Ludwig, 2008) was used to construct all concordia diagrams and perform all age determinations. During the analyses conducted in this study, a weighted mean ${ }^{206} \mathrm{~Pb} /{ }^{238} \mathrm{U}$ age of $1102 \pm 9 \mathrm{Ma}$ was obtained for standard FC-1 (95\% confidence interval, $\mathrm{N}=10)$, which is con- 


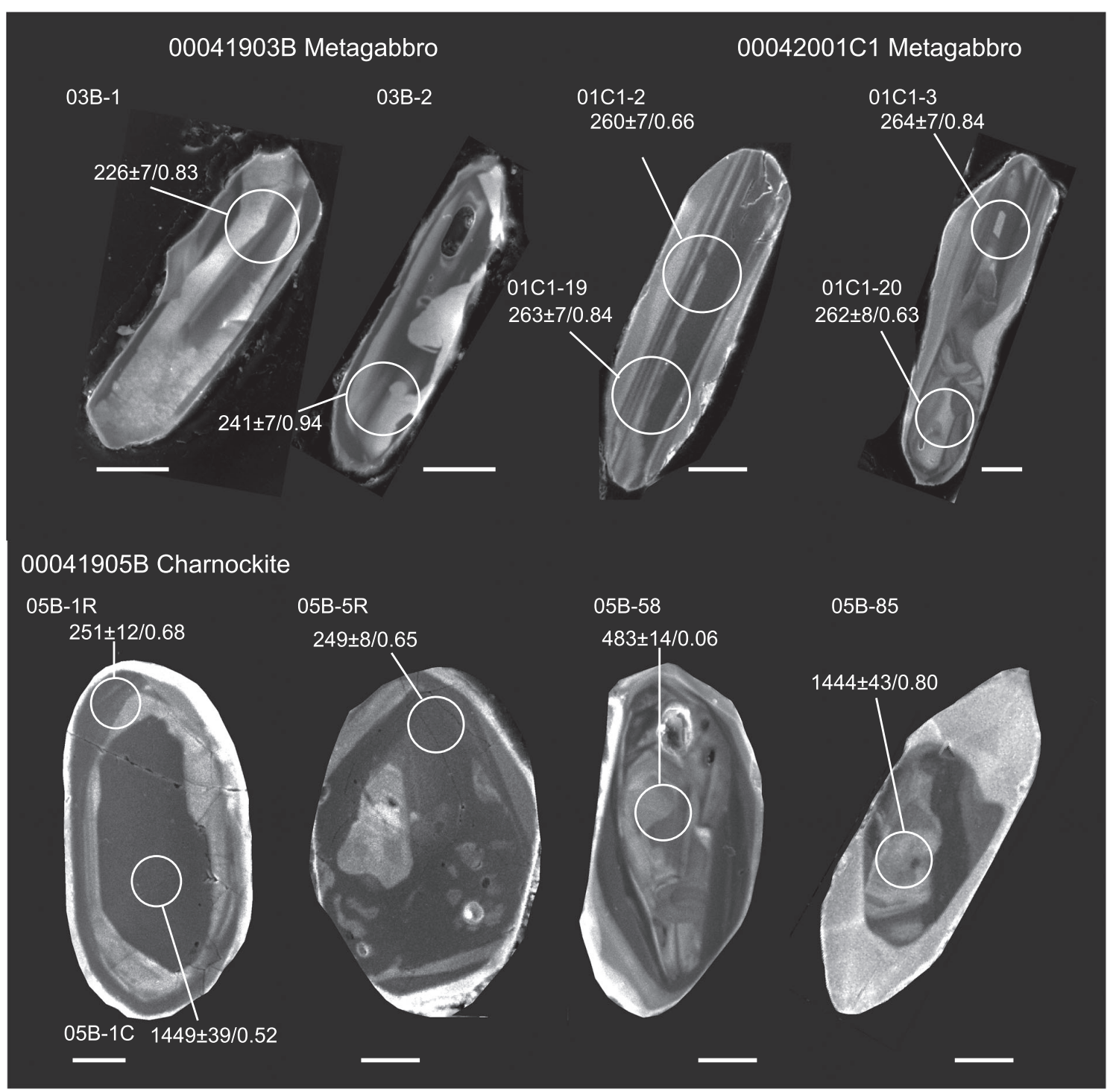

Figure 4. Representative cathodoluminescence images of zircon grains from dated samples. Circles indicate the locations of analytical spots, which are labeled with analysis numbers. Each image also shows individual ${ }^{206} \mathrm{~Pb} /{ }^{238} \mathrm{U}$ ages (Ma) with $2 \sigma$ errors, $\mathrm{Th} / \mathrm{U}$ ratios, and a $30-\mu \mathrm{m}$ scale bar. Color version is available online from http://doi.org/10.2465/jmps.151019b.

sistent with its reported age of $1100 \mathrm{Ma}$ (Paces and Miller, 1993). Cathodoluminescence images showing the internal structures of zircon grains, and the ages and $\mathrm{Th} / \mathrm{U}$ ratios for analyzed samples are shown in Figure 4. All results are presented in Supplemental Table S1 (available online from http://doi.org/10.2465/jmps.151019b) and concordia diagrams are shown in Figure 5.

Zircon grains analyzed from metagabbro samples exhibit elongated shapes with oscillatory internal zoning and have $\mathrm{Th} / \mathrm{U}$ ratios $>0.1$, indicative of a magmatic origin. By contrast, zircon grains analyzed from the charnockite sample show rounded shapes and have clear rims with inherited cores (Fig. 4). The $\mathrm{Th} / \mathrm{U}$ ratios of these grains are mostly $>0.1$, regardless of analyzed positions, although some core domains have ratios $<0.1$ (Table S1 and Fig. 4).
Metagabbro (sample 00041903B). This sample occurred in the field as an enclave together within charnockite. The zircon grains in this sample do not have inherited cores and show clear igneous zoning (Fig. 4). The majority of analyses produced concordant data, although the small number of discordant data produced ages that were slightly younger than for the former (Fig. 5a), suggesting that some degree of $\mathrm{Pb}$-loss occurred following metagabbro emplacement. Data that were discordant by more than $5 \%$ were omitted from calculations, which produced a weighted mean ${ }^{206} \mathrm{~Pb} /{ }^{238} \mathrm{U}$ age of $250 \pm 4 \mathrm{Ma}$ (Fig. 5a).

Metagabbro (sample 00042001C1). Akin to metagabbro sample 00041903B, sample 00042001C1 occurred in the field as an enclave, although was included within garnet-bearing granite instead of charnockite. Zircon 


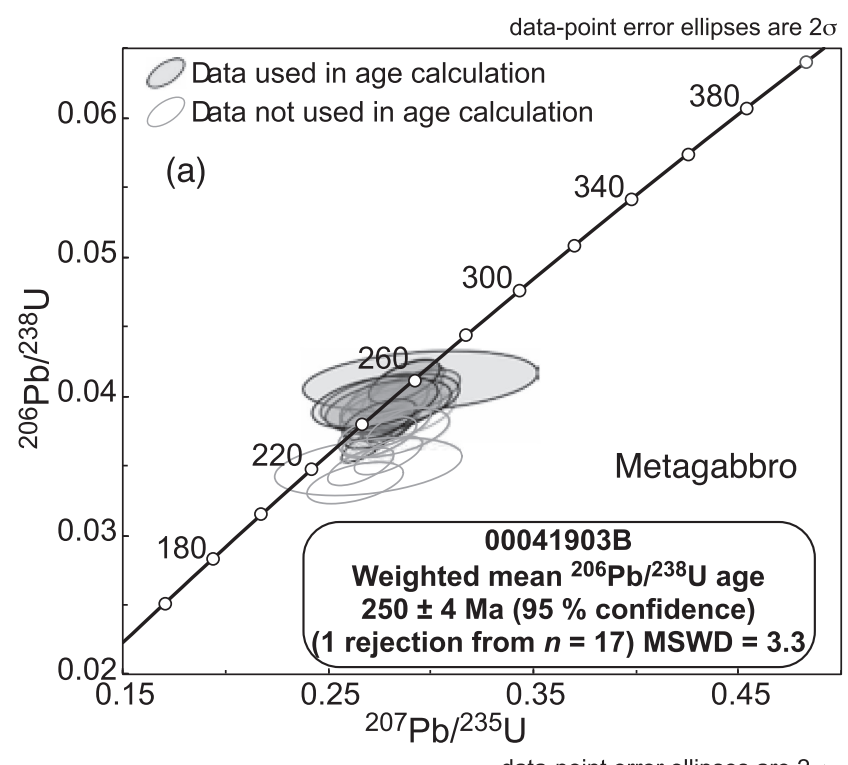

Figure 5. Concordia diagrams showing the results of LA-ICP-MS $\mathrm{U}-\mathrm{Pb}$ dating of zircon from Kannak Complex metagabbro and charnockite. (a) Weighted-average mean ${ }^{206} \mathrm{~Pb} /{ }^{238} \mathrm{U}$ age for metagabbro sample 00041903B. (b) Concordia age for metagabbro sample 00042001C1. (c) Concordant data for metagabbro sample 00042001C1. (d) Concordia age for charnockite sample 00041905B. (e) Concordant data for charnockite sample 00041905B. Color version is available online from http:// doi.org/10.2465/jmps.151019b.
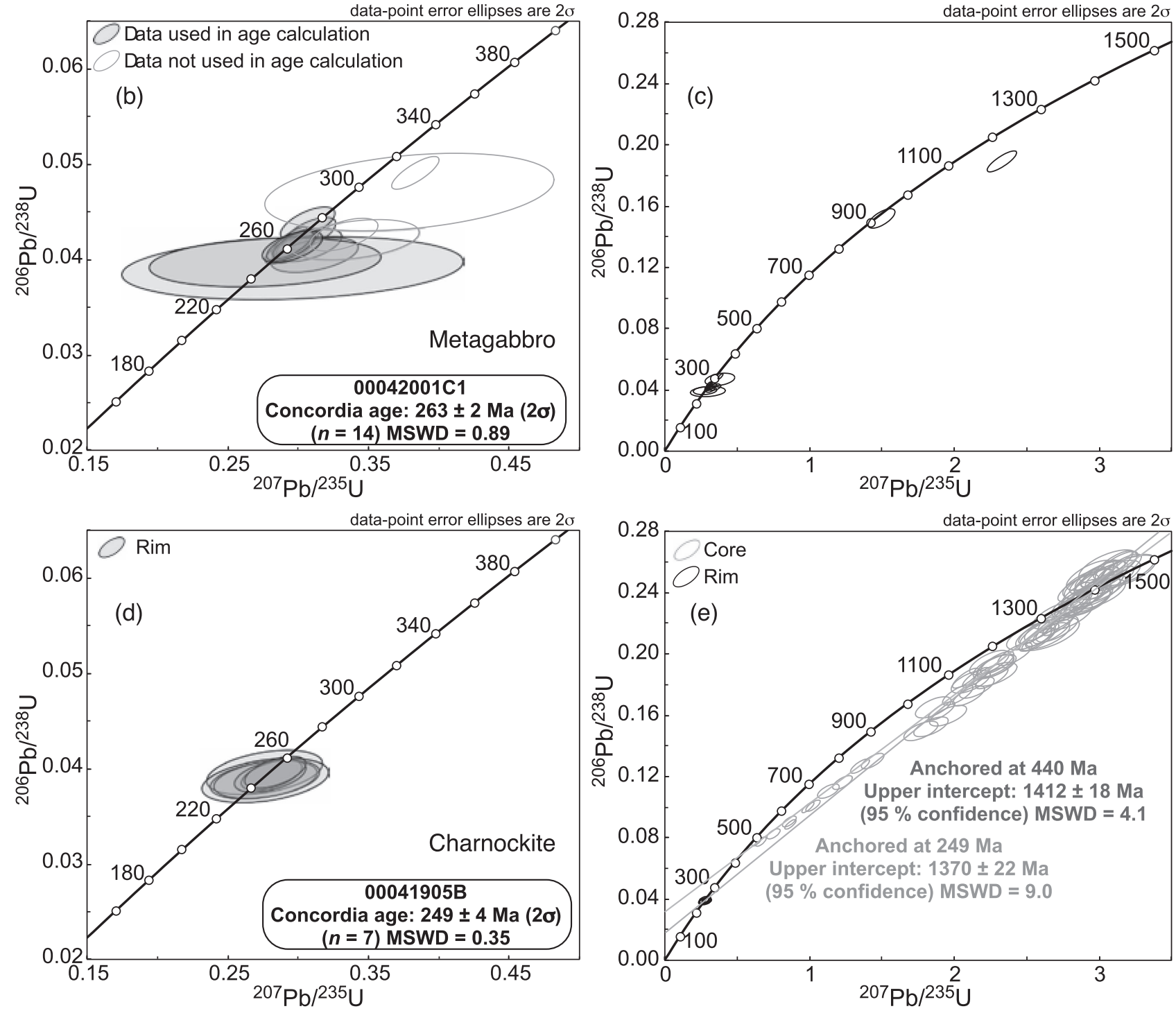
grains in this sample have elongate shapes and show clear zoning patterns that are similar to those from sample 00041903B; however, some contained inherited cores that produced discordant isotopic data (Figs. $5 \mathrm{~b}$ and $5 \mathrm{c}$ ). A concordia age of $263 \pm 2$ Ma (Fig. 5b) was obtained from zoned zircon cores after these discordant data were omitted. This age is consistent with that of $264 \pm 4 \mathrm{Ma}$ for garnet-bearing granite from the same locality, which was obtained by Owada et al. (2006) via electron probe microanalyzer (EPMA) Th-U-Pb dating of monazite.

Charnockite (sample 00041905B). This sample contains rounded zircon grains that have inherited cores and thin rims. All rim analyses showed concordant ages and yielded a concordia age of $249 \pm 4 \mathrm{Ma}$ (Fig. 5d), which is consistent with that of metagabbro sample 00041903B, but younger than that of metagabbro sample $00042001 \mathrm{C} 1$. The data obtained from inherited cores in this sample were discordant (Fig. 5e) and defined a discordia line that has an upper intercept age of $1412 \pm 18$ $\mathrm{Ma}$ and a lower intercept age of $\sim 440 \mathrm{Ma}$ (Silurian).

The U-Pb zircon dating performed for these samples indicates that magmatic activity in the Kontum Massif occurred during the Late Permian, which is very similar to the timing of mafic igneous activity documented in the Song Da area (260-250 Ma: Usuki et al., 2015) situated $300 \mathrm{~km}$ north of the Kontum Massif.

\section{MAJOR AND TRACE ELEMENT GEOCHEMISTRY}

Major-element abundances in the Kontum Massif metagabbro samples were determined via $\mathrm{X}$-ray fluorescence (XRF) using a RIX-3000 housed at the Center for Instrumental Analyses, Yamaguchi University. The analytical procedure utilized has been described in detail by Yamasaki et al. (1999). Trace element and rare earth element (REE) contents were analyzed using an ICP-MS at Actlabs Ltd., Canada. All data are given in Table 1.

$\mathrm{SiO}_{2}$ contents of all samples range from 45 to 53 $w t \%$. Most data lie within the non-alkaline field on a total alkali-silica (TAS) diagram, but are scattered with respect to increasing $\mathrm{SiO}_{2}$ (Fig. 6a). Because high-field-strength elements are believed to be immobile during metamorphism (Winchester and Floyd, 1977), a plot of $\mathrm{Zr} / \mathrm{TiO}_{2}$ against $\mathrm{Nb} / \mathrm{Y}$ is widely used as an immobile element proxy for the TAS diagram. A $\mathrm{Nb} / \mathrm{Y}-\mathrm{Zr} / \mathrm{TiO}_{2}$ diagram is shown in Figure 6b, where it can be seen that the Kontum Massif metagabbros lie within the subalkaline basalt field. A Mg\# versus $\mathrm{Ti} / \mathrm{Y}$ diagram, where $\mathrm{Mg} \#=\mathrm{MgO} /$ $(\mathrm{FeO}+\mathrm{MgO})$, shows that the metagabbros have $\mathrm{Ti} / \mathrm{Y}$ ratios less than 500 (Fig. 6c). The chemical compositions of mafic rocks from the Song Da igneous suite are also
Table 1. Whole-rock chemical analyses of metagabbro samples

\begin{tabular}{|c|c|c|c|c|c|c|c|}
\hline $\begin{array}{l}\text { Sp. } \\
\text { No. }\end{array}$ & $\begin{array}{c}000 \\
41907 \\
E\end{array}$ & $\begin{array}{c}000 \\
42001 \\
\text { B }\end{array}$ & $\begin{array}{c}000 \\
41903 \\
\text { B }\end{array}$ & $\begin{array}{c}000 \\
41910 \\
\text { B1 }\end{array}$ & $\begin{array}{c}000 \\
42001 \\
\mathrm{Cl}\end{array}$ & $\begin{array}{c}000 \\
41906 \\
\text { A }\end{array}$ & $\begin{array}{c}000 \\
41907 \\
\mathrm{C}\end{array}$ \\
\hline wt $\%$ & & & & & & & \\
\hline $\mathrm{SiO}_{2}$ & 49.51 & 48.36 & 45.25 & 50.05 & 51.90 & 49.69 & 45.26 \\
\hline $\mathrm{TiO}_{2}$ & 1.42 & 1.46 & 1.94 & 1.49 & 1.07 & 1.41 & 1.48 \\
\hline $\mathrm{Al}_{2} \mathrm{O}_{3}$ & 13.62 & 15.51 & 19.19 & 17.84 & 14.34 & 13.52 & 16.37 \\
\hline $\mathrm{Fe}_{2} \mathrm{O}_{3}$ & 16.96 & 12.72 & 12.21 & 10.34 & 14.29 & 16.03 & 18.54 \\
\hline $\mathrm{MnO}$ & 0.26 & 0.19 & 0.17 & 0.13 & 0.21 & 0.24 & 0.25 \\
\hline $\mathrm{MgO}$ & 6.68 & 8.26 & 5.36 & 5.27 & 7.58 & 6.71 & 7.09 \\
\hline $\mathrm{CaO}$ & 9.79 & 13.17 & 11.12 & 8.13 & 10.33 & 10.32 & 6.44 \\
\hline $\mathrm{Na}_{2} \mathrm{O}$ & 0.37 & 0.59 & 1.64 & 3.60 & 0.45 & 2.02 & 0.64 \\
\hline $\mathrm{K}_{2} \mathrm{O}$ & 0.86 & 0.55 & 1.17 & 2.03 & 0.16 & 0.51 & 1.91 \\
\hline $\mathrm{P}_{2} \mathrm{O}_{5}$ & 0.07 & 0.09 & 0.42 & 0.18 & 0.08 & 0.07 & 0.05 \\
\hline Total & 99.55 & 100.90 & 98.47 & 99.06 & 100.40 & 100.52 & 98.03 \\
\hline $\mathrm{ppm}$ & & & & & & & \\
\hline $\mathrm{V}$ & 412 & 247 & 165 & 183 & 300 & 299 & 354 \\
\hline $\mathrm{Cr}$ & 87 & 235 & $<20$ & 60 & 164 & 82 & 91 \\
\hline Co & 53 & 48 & 22 & 24 & 52 & 42 & 58 \\
\hline $\mathrm{Ni}$ & 73 & 63 & $<20$ & 23 & 58 & 51 & 57 \\
\hline $\mathrm{Cu}$ & 50 & 34 & 17 & 30 & 27 & 35 & 72 \\
\hline $\mathrm{Zn}$ & 115 & 93 & 96 & 71 & 102 & 112 & 217 \\
\hline $\mathrm{Ga}$ & 16 & 16 & 20 & 21 & 16 & 15 & 22 \\
\hline $\mathrm{Rb}$ & 55 & 15 & 73 & 43 & 11 & 12 & 149 \\
\hline $\mathrm{Sr}$ & 69 & 158 & 372 & 398 & 110 & 50 & 45 \\
\hline $\mathrm{Y}$ & 36 & 23 & 42 & 30 & 18 & 24 & 30 \\
\hline $\mathrm{Zr}$ & 74 & 81 & 291 & 146 & 51 & 84 & 81 \\
\hline $\mathrm{Nb}$ & 3 & 9 & 14 & 12 & 6 & 7 & 4 \\
\hline $\mathrm{Ba}$ & 88 & 31 & 395 & 376 & 40 & 49 & 448 \\
\hline $\mathrm{La}$ & 4.22 & 6.81 & 28.0 & 34.0 & 7.27 & 7.95 & 5.77 \\
\hline $\mathrm{Ce}$ & 12.1 & 17.0 & 73.9 & 86.5 & 17.9 & 18.6 & 13.6 \\
\hline $\mathrm{Pr}$ & 1.78 & 2.21 & 9.64 & 10.7 & 2.22 & 2.40 & 1.67 \\
\hline $\mathrm{Nd}$ & 9.43 & 10.4 & 42.6 & 44.9 & 10.1 & 11.0 & 7.52 \\
\hline $\mathrm{Sm}$ & 3.33 & 2.99 & 9.23 & 9.24 & 2.50 & 3.07 & 2.16 \\
\hline $\mathrm{Eu}$ & 1.04 & 1.18 & 1.94 & 1.93 & 0.919 & 1.07 & 0.885 \\
\hline $\mathrm{Gd}$ & 4.73 & 3.63 & 8. & 7.92 & 2.95 & 3.65 & 2.88 \\
\hline $\mathrm{Tb}$ & 0.945 & 0.687 & 1.39 & 1.14 & 0.520 & 0.669 & 0.595 \\
\hline Dy & 5.82 & 3.87 & 7.56 & 5.58 & 2.98 & 4.18 & 4.23 \\
\hline Ho & 1.30 & 0.829 & 1.54 & 1.06 & 0.670 & 0.921 & 1.07 \\
\hline $\mathrm{Er}$ & 3.89 & 2.37 & 4.36 & 2.87 & 1.87 & 2.68 & 3.37 \\
\hline $\mathrm{Tm}$ & 0.594 & 0.364 & 0.658 & 0.409 & 0.293 & 0.413 & 0.568 \\
\hline $\mathrm{Yb}$ & 3.71 & 2.08 & 3.81 & 2.36 & 1.75 & 2.49 & 3.66 \\
\hline $\mathrm{Lu}$ & 0.578 & 0.316 & 0.578 & 0.350 & 0.272 & 0.397 & 0.610 \\
\hline $\mathrm{Hf}$ & 2.23 & 2.27 & 7.20 & 3.73 & 1.47 & 2.36 & 2.51 \\
\hline $\mathrm{Ta}$ & 0.072 & 0.449 & 0.755 & 0.554 & 0.270 & 0.399 & 0.441 \\
\hline $\mathrm{Pb}$ & $<5$ & & $<5$ & $<5$ & $<5$ & $<5$ & 5 \\
\hline Th & 0.43 & 0.65 & 1.1 & 0.52 & 0.45 & 0.68 & 0.52 \\
\hline $\mathrm{U}$ & 0.37 & 0.20 & 0.64 & 0.21 & 0.090 & 0.40 & 0.76 \\
\hline
\end{tabular}

plotted, indicating that the compositions of the Kontum Massif metagabbros considered herein overlap with those of the low-Ti series of the Song Da igneous suite.

Chondrite-normalized REE patterns and primitive mantle-normalized trace element patterns for the Kontum Massif metagabbros are shown in Figure 7. These units mostly show flat REE patterns; however, two samples show elevated light REE/heavy REE (LREE/HREE) ratios with slightly negative Eu anomalies (Fig. 7a). All samples show a negative $\mathrm{P}$ anomaly (Fig. 7b). In addition, the two high-LREE/HREE samples shown in Figure 7a possess negative $\mathrm{Nb}$, Ta, and $\mathrm{Ti}$ anomalies with $\mathrm{Nb}$, $\mathrm{Ta}$, and Ti negative anomalies; however, all other sam- 

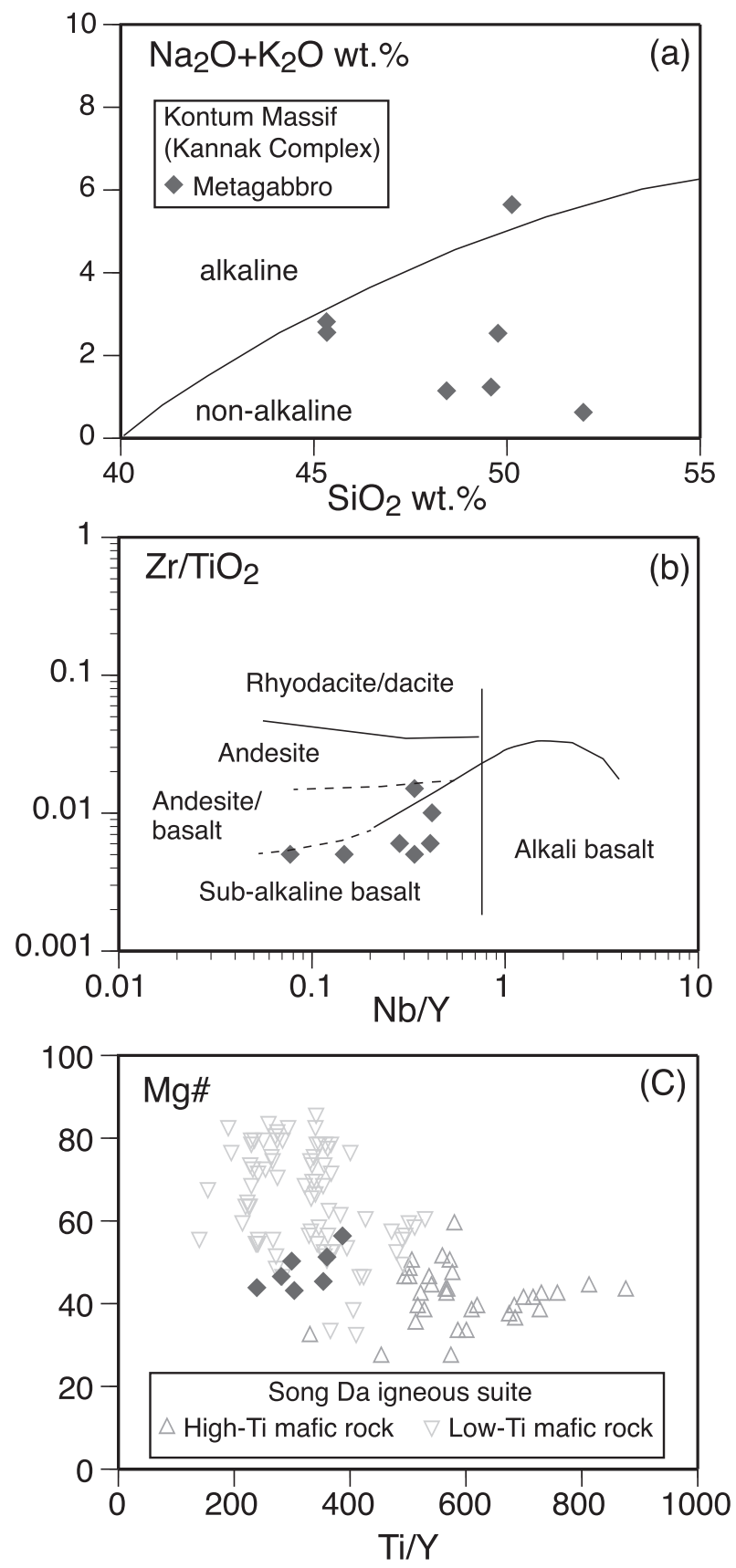

Figure 6. Discrimination diagrams for metagabbro from the Kannak Complex. (a) Total alkali-SiO $2 \mathrm{wt} \%$ diagram, with the line separating alkaline and non-alkaline fields drawn after Miyashiro (1978). (b) $\mathrm{Zr} / \mathrm{TiO}_{2}-\mathrm{Nb} / \mathrm{Y}$ diagram (after Winchester and Floyd, 1977). (c) Mg\#-Ti/Y diagram for metagabbro from the Kannak Complex and mafic rocks from the Song Da igneous suite. Chemical compositions of the Song Da igneous suite are taken from Hanski et al. (2004), Wang et al. (2007), and Tran Viet Anh et al. (2011). Data for metagabbros from the Song $\mathrm{Ba}$ area lie within the compositional range of low-Ti mafic rocks from the Song Da igneous suite. $\mathrm{Mg} \#$ : $100 * \mathrm{MgO} /\left(\mathrm{FeO}^{*}+\right.$ $\mathrm{MgO})$ mole ratio. Color version is available online from http:// doi.org/10.2465/jmps.151019b. ples show fairly flat patterns, except for the concentrations of large ion lithophile elements (Fig. 7b).

\section{Sr-Nd ISOTOPIC ANALYSIS}

Strontium (Sr) and neodymium (Nd) separation was performed at Yamaguchi University using an experimental procedure adopted from Kagami et al. (1987). Isotopic analyses were carried out using a thermal ionization mass spectrometer (MAT 262) at Niigata University.

Measured ratios of ${ }^{87} \mathrm{Sr} /{ }^{86} \mathrm{Sr}$ and ${ }^{143} \mathrm{Nd} /{ }^{144} \mathrm{Nd}$ were normalized to ${ }^{86} \mathrm{Sr} /{ }^{88} \mathrm{Sr}$ and ${ }^{146} \mathrm{Nd} /{ }^{144} \mathrm{Nd}$ values of 0.1194 and 0.7219 , respectively. These normalized ${ }^{87} \mathrm{Sr} /{ }^{86} \mathrm{Sr}$ and ${ }^{143} \mathrm{Nd} /{ }^{144} \mathrm{Nd}$ ratios were corrected using the NIST-987 standard ${ }^{87} \mathrm{Sr} /{ }^{86} \mathrm{Sr}$ value of 0.710241 and the JNdi-1 (Nd isotopic reference material of the Geological Survey of Japan) standard ${ }^{143} \mathrm{Nd} /{ }^{144} \mathrm{Nd}$ value of 0.512106 , which has been verified using the international standard La Jolla ${ }^{143} \mathrm{Nd} /{ }^{144} \mathrm{Nd}$ value of 0.511849 (Tanaka et al., 2000). Concentrations of $\mathrm{Rb}, \mathrm{Sr}, \mathrm{Sm}$, and $\mathrm{Nd}$ were measured via ICP-MS. Analytical errors associated with both ${ }^{87} \mathrm{Rb} /$ ${ }^{86} \mathrm{Sr}$ and ${ }^{147} \mathrm{Sm} /{ }^{144} \mathrm{Nd}$ measurements were $1 \%(1 \sigma)$. The initial $\mathrm{Sr}$ and $\mathrm{Nd}$ isotope ratios ( $\mathrm{SrI}$ and $\mathrm{NdI}$ ) were calculated using the decay constants: $\lambda^{87} \mathrm{Rb}=1.42 \times 10^{-11} / \mathrm{y}$ (Steiger and Jäger, 1977) and $\lambda^{147} \mathrm{Sm}=6.54 \times 10^{-12} / \mathrm{y}$ (Lugmair and Marti, 1978).

All $\mathrm{Rb}-\mathrm{Sr}$ and $\mathrm{Sm}-\mathrm{Nd}$ isotopic data are given in Table 2. Sample SrI and NdI values were calculated for an age of $260 \mathrm{Ma}$. Epsilon $\mathrm{Sr}$ and $\mathrm{Nd}$ values were calculated using the following CHUR data: ${ }^{87} \mathrm{Rb} /{ }^{86} \mathrm{Sr}=$ $0.0827,{ }^{87} \mathrm{Sr} /{ }^{86} \mathrm{Sr}=0.7045,{ }^{147} \mathrm{Sm} /{ }^{144} \mathrm{Nd}=0.1966$ and ${ }^{143} \mathrm{Nd} /{ }^{144} \mathrm{Nd}=0.512638$. Figure 8 shows a $\varepsilon \mathrm{Sr}$ and $\varepsilon \mathrm{Nd}$ diagram corrected for the time-integrated effects of a 260 Ma age, $\varepsilon \operatorname{Sr}(t)$ and $\varepsilon \operatorname{Nd}(t)$, respectively, for metagabbro and previously reported isotopic compositions of granitic and metamorphic rocks from the Kontum Massif. Figure 8 also plots isotopic data for high-Ti and low-Ti mafic rocks from the Song $\mathrm{Da}$ igneous suite. Although the metagabbro appears to be heterogeneous with respect to $\mathrm{Sr}$ and $\mathrm{Nd}$ isotopic signatures, its $\varepsilon \mathrm{Nd}(t)$ values range from +4 to -9 and resemble those of mafic rocks from the Song Da igneous suite (Fig. 8).

\section{DISCUSSION}

\section{Reworked continental crust in the Kontum Massif}

Detailed geochronological and petrological studies of metamorphic and igneous rocks can significantly improve our understanding of the tectonic processes that occur in orogenic belts. The Late Permian-Early Triassic metamorphic rocks in the Kontum Massif, south Viet- 

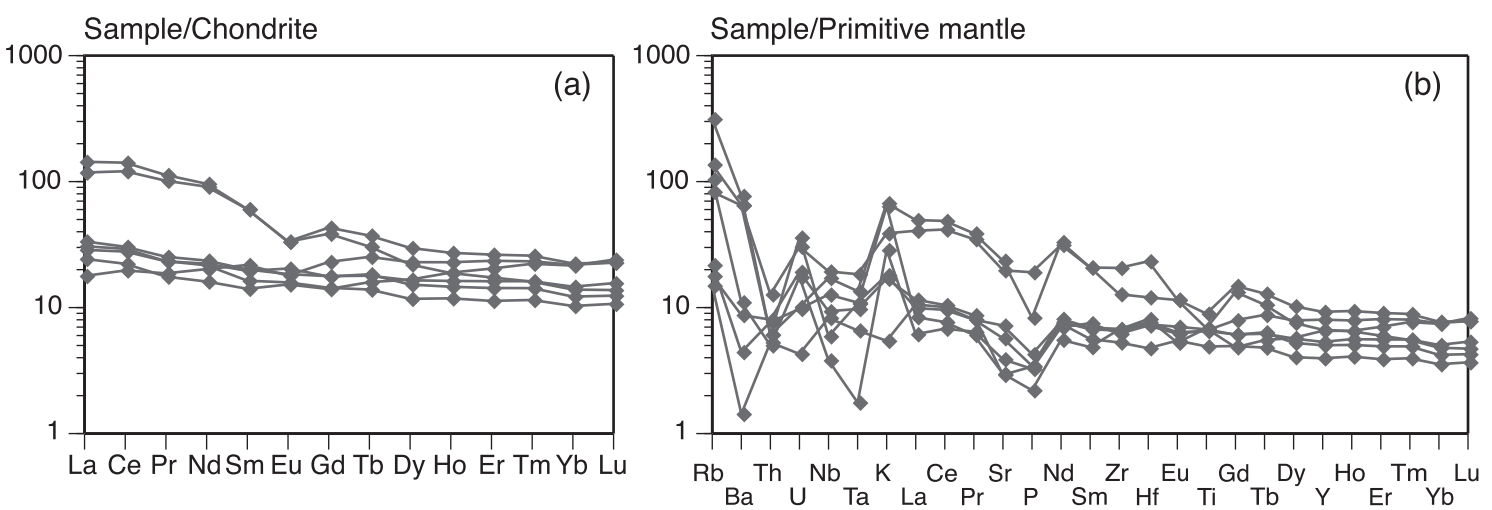

Figure 7. (a) Chondrite-normalized REE diagram and (b) primitive mantle-normalized spider diagram for metagabbro from the Song Ba area. Normalized values are quoted from Sun and McDonough (1989). Color version is available online from http://doi.org/10.2465/jmps. 151019b.

Table 2. Results of $\mathrm{Sr}$ and $\mathrm{Nd}$ isotopic analyses for whole-rock samples

\begin{tabular}{|c|c|c|c|c|c|c|c|c|c|c|}
\hline Sample No. & & $\begin{array}{c}\mathrm{Rb} \\
(\mathrm{ppm})\end{array}$ & $\begin{array}{c}\mathrm{Sr} \\
(\mathrm{ppm})\end{array}$ & ${ }^{87} \mathrm{Rb} /{ }^{86} \mathrm{Sr}$ & ${ }^{87} \mathrm{Sr} /{ }^{86} \mathrm{Sr}$ & $2 \sigma$ & $\begin{array}{c}\text { SrI } \\
260 \mathrm{Ma}\end{array}$ & $\begin{array}{c}\varepsilon \mathrm{SrI} \\
260 \mathrm{Ma}\end{array}$ & $\begin{array}{c}\mathrm{Nd} \\
(\mathrm{ppm})\end{array}$ & $\begin{array}{c}\mathrm{Sm} \\
(\mathrm{ppm})\end{array}$ \\
\hline $00041907 \mathrm{E}$ & & 55 & 69 & 2.316 & 0.73606 & 1 & 0.72749 & 330.77 & 9.43 & 3.33 \\
\hline 00042001B & & 15 & 158 & 0.2650 & 0.71064 & 1 & 0.70966 & 77.55 & 10.4 & 2.99 \\
\hline 00041903B & & 73 & 372 & 0.5717 & 0.71558 & 1 & 0.71346 & 131.55 & 42.6 & 9.23 \\
\hline 00041910B1 & Metagabbro & 43 & 398 & 0.3164 & 0.71120 & 1 & 0.71003 & 82.81 & 44.9 & 9.24 \\
\hline $00042001 \mathrm{C} 1$ & & 11 & 110 & 0.2901 & 0.73481 & 1 & 0.73373 & 419.41 & 10.1 & 2.50 \\
\hline 00041906A & & 12 & 50 & 0.6994 & 0.71703 & 1 & 0.71444 & 145.47 & 11.0 & 3.07 \\
\hline 00041907C & & 149 & 45 & 9.664 & 0.77029 & 1 & 0.73455 & 430.99 & 7.52 & 2.16 \\
\hline 00041911 & Charnockite & $35^{*}$ & $382 *$ & 0.265 & 0.71679 & 1 & 0.71581 & 164.85 & 13.0 & 2.41 \\
\hline
\end{tabular}

${ }^{*}$ Data are quoted from Owada et al. (2007).

Table 2. (Continued)

\begin{tabular}{ccccc}
\hline${ }^{147} \mathrm{Sm} /{ }^{144} \mathrm{Nd}$ & ${ }^{143} \mathrm{Nd} /{ }^{144} \mathrm{Nd}$ & \multicolumn{2}{c}{$\mathrm{NdI}$} & $\varepsilon \mathrm{NdI}$ \\
& & $2 \sigma$ & $260 \mathrm{Ma}$ & $260 \mathrm{Ma}$ \\
\hline 0.2135 & 0.512874 & 14 & 0.512511 & 4.09 \\
0.1738 & 0.512778 & 14 & 0.512482 & 3.54 \\
0.1311 & 0.512016 & 14 & 0.511793 & -9.92 \\
0.1245 & 0.512134 & 14 & 0.511922 & -7.40 \\
0.1496 & 0.512224 & 14 & 0.511969 & -6.47 \\
0.1687 & 0.512414 & 14 & 0.512127 & -3.40 \\
0.1736 & 0.512523 & 14 & 0.512227 & -1.44 \\
0.1121 & 0.512036 & 14 & 0.511845 & -8.90 \\
\hline
\end{tabular}

nam, correspond well with the metamorphic characteristics of a collision between the Indochina and South China cratons in terms of peak $P-T$ conditions and the timescales of deformation (Osanai et al., 2008).

Tran Ngoc Nam et al. (2001) reported evidence of Middle Proterozoic inherited zircon ages in pelitic gneiss from the Kannak Complex. Moreover, monazite grains in pelitic gneisses from the Kannak and Ngoc Linh Complexes locally include Middle Proterozoic cores (Nakano et al., 2013). These Middle Proterozoic ages are only recorded in detrital grains and so their origin remains un-

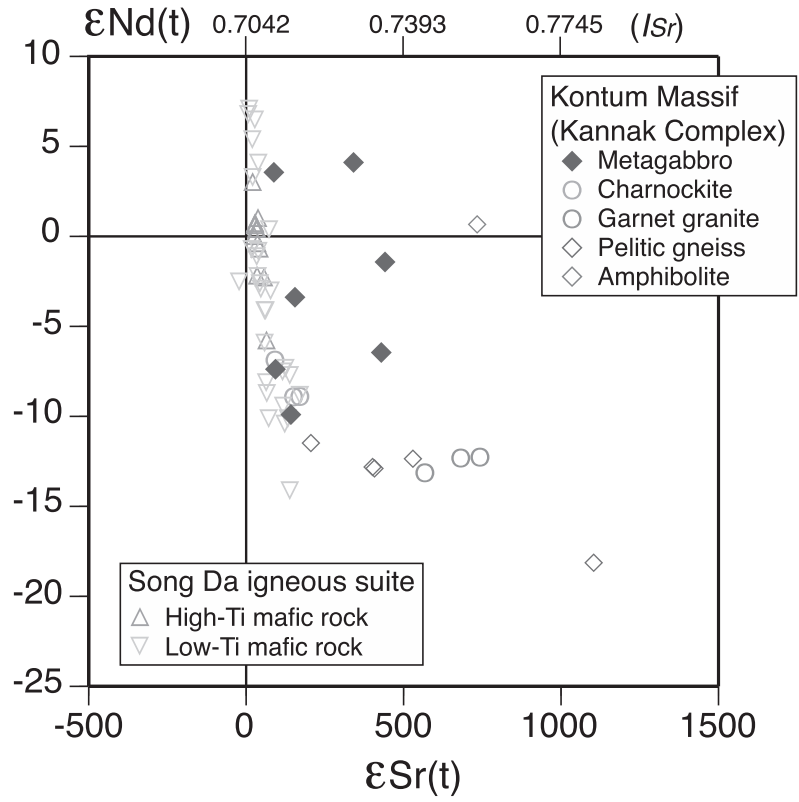

Figure 8. $\varepsilon \operatorname{Sr}(t)-\varepsilon \operatorname{Nd}(t)$ diagram for metagabbro and other rock types from the Kannak Complex. Isotopic data for mafic rocks from the Song Da igneous suite are also shown, which are taken from Lan et al. (2003), Owada et al. (2007), Wang et al. (2007), Tran Viet Anh et al. (2011), and this study. Sr and Nd isotopic data were corrected to an age of $260 \mathrm{Ma}$. Color version is available online from http://doi.org/10.2465/jmps.151019b. 
known. In this work, $\mathrm{U}-\mathrm{Pb}$ analyses obtained from zircon in charnockite lie upon a well-defined discordia line (Fig. $5 \mathrm{e}$ ), suggesting that the parental rock of the charnockite may have been derived from magmatic activity that occurred at $\sim 1400$ Ma. Lan et al. (2003) proposed that some mafic granulites from the Kannak Complex possess $\varepsilon \mathrm{Nd}(t)$ values of -8.7 , which is similar to that of the charnockite studied herein. In addition, Nd model ages of Kontum Massif charnockites lie in the range 1500-1900 Ma (Lan et al., 2003). These charnockites have geochemical characteristics of I-type granite and were likely produced via partial melting of a mafic granulite protolith, according to $\mathrm{Sr}-\mathrm{Nd}$ isotopic signatures and trace-element geochemical modeling performed by Owada et al. (2007). Based on the concordia age of 249 Ma obtained from constituent zircon rims in this work, the charnockite magma is interpreted to have formed via partial melting of metamorphosed mafic rocks during Permian high-grade metamorphism. The lower intercept of Silurian age ( $440 \mathrm{Ma}$ : Fig. 5 e) suggests that the charnockite source rock would have undergone metamorphism at this time.

Given that geochronological data have revealed the occurrence of Silurian magmatism within the Kontum Massif (Fig. 2), the Late Permian tectonothermal event must have overprinted Silurian units, meaning that the Kontum Massif contains reworked crust. The charnockite studied here shows Silurian and Middle Proterozoic intercept ages (Fig. 5e) alongside a $\varepsilon \mathrm{Nd}(t)$ value of -9 (Table 2), indicating that it may have been derived from old continental crust, probably of Middle Proterozoic age.

\section{Timing of mantle-derived magma emplacement}

$\mathrm{U}-\mathrm{Pb}$ sensitive high-resolution ion microprobe dating of zircon from metamorphic rocks of the Kannak Complex has yielded ages of 260-250 Ma (Carter et al., 2001; Tran Ngoc Nam et al., 2001), which are thought to date peak metamorphism (Osanai et al., 2008). Owada et al. (2006) performed EPMA Th-U-Pb monazite dating of garnetbearing granite, and garnet- and orthopyroxene-bearing gneiss, and concluded that the timing of formation of crustal-derived granite overlapped with the age of peak metamorphism; thus, crystallization of garnet-bearing granite in the Kontum Massif is assumed to have been simultaneous with peak metamorphism.

Figure 2 indicates that most of the igneous activity documented from the Kontum Massif occurred between the Late Permian and Early Triassic. According to Osanai et al. (2004, 2008) and Nakano et al. (2013), collision between the South China and Indochina cratons caused regional metamorphism during this same time period. The Late Permian-Early Triassic igneous lithologies in the Kontum Massif would therefore represent syn- to post-collisional magmatism.

Owada et al. $(2006,2007)$ and Osanai et al. (2008) also inferred that a significantly high geothermal gradient was required to produce the HT/UHT metamorphism documented in the Ngoc Linh and Kannak Complexes. Metagabbro lenses within host gneisses show magmatic ages of 260-250 Ma, which are similar to metamorphic ages recorded for HT and UHT rocks from the Ngoc Linh and Kannak Complexes. Considering the field relationships and newly determined zircon $\mathrm{U}-\mathrm{Pb}$ ages for the metagabbro described herein, we interpret that mantlederived magma played an important role as a heat source to drive HT/UHT metamorphism.

\section{Magmatic process of metagabbro formation}

$\mathrm{U}-\mathrm{Pb}$ dating of zircon from metagabbro confirms that magmatic activity occurred in the Kontum Massif during the Late Permian (260-250 Ma). At this time, a major LIP component, the Song Da igneous suite, is thought to have formed in the northern part of the TVOB (Fig. 1: Hanski et al., 2004; Wang et al., 2007; Tran Viet Anh, 2011; Usuki et al., 2015). Moreover, as the Nd isotopic compositions of the Kontum Massif metagabbros resemble those of the Song Da mafic rocks (Fig. 8), it appears likely that magmatism in both regions was connected.

Zircon $\mathrm{U}-\mathrm{Pb}$ dating, $\mathrm{Nd}$ isotopic compositions, and LREE/HREE ratios of metagabbro all unravel the relationships between it and the Song Da mafic magmatism. Figure $9 \mathrm{a}$ shows chondrite-normalized $\mathrm{La} / \mathrm{Yb}$ ratios and $\varepsilon \operatorname{Nd}(t)$ values for both suites. The most depleted $\varepsilon \operatorname{Nd}(t)$ sample of the Kontum Massif metagabbros has a high value of +4 , which is similar to those for the Song $\mathrm{Da}$ mafic rocks (Fig. 9a). Such depleted $\varepsilon N d(t)$ mafic rocks from the Song $\mathrm{Da}$ igneous suite were derived from a mantle plume and correspond with the southern extension of the Emeishan LIP (Hanski et al., 2004; Wang et al., 2007; Hanski et al., 2010; He et al., 2010; Tran Viet Anh et al., 2011; Vladimirov et al., 2012; Usuki et al., 2015). Conversely, enriched $\varepsilon \mathrm{Nd}(t)$ mafic rocks from the Emeishan LIP, including those at Song Da, are thought to have formed from interaction between depleted mafic magma and enriched lithosphere, the latter including crustal rocks (Chung and Jahn, 1995; Wang et al., 2007; Hanski et al., 2010; Tran Viet Anh et al., 2011; Shellnutt, 2014). The enriched $\varepsilon \mathrm{Nd}(t)$ rocks possess high-LREE/HREE ratios (Chung and Jahn, 1995), and values for the Kontum Massif metagabbros overlap with those of the Song Da mafic units (Fig. 9a).

Figure $9 \mathrm{~b}$ shows a $\varepsilon \mathrm{Nd}(t)-\mathrm{Nb} / \mathrm{La}$ ratio diagram that plots values for the Kontum Massif metagabbro and units 

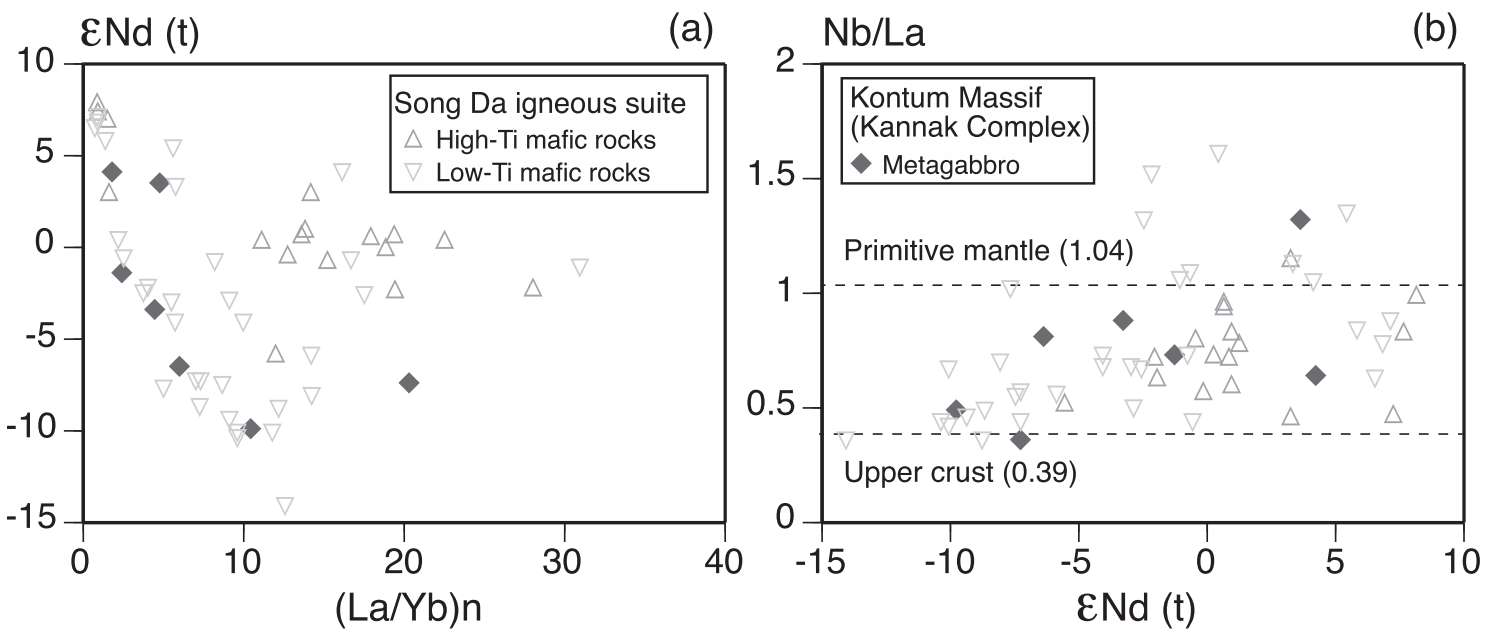

Figure 9. Binary plots related to magma-crust interaction for metagabbro and Late Permian Song Da mafic rocks. (a) Chondrite-normalized $\mathrm{La} / \mathrm{Yb}-\varepsilon \mathrm{Nd}(t)$ diagram. (b) $\varepsilon \mathrm{Nd}(\mathrm{t})-\mathrm{Nb} / \mathrm{La}$ diagram (after Peate, 1997). Primitive mantle and upper crust values are after McDonough and Sun (1995) and Rudnick and Gao (2003). Data for the Song Da mafic rocks are from Hanski et al. (2004), Wang et al. (2007), and Tran Viet Anh et al. (2011). Nd isotopic data were corrected to an age of $260 \mathrm{Ma}$. Color version is available online from http://doi.org/10.2465/ jmps.151019b.
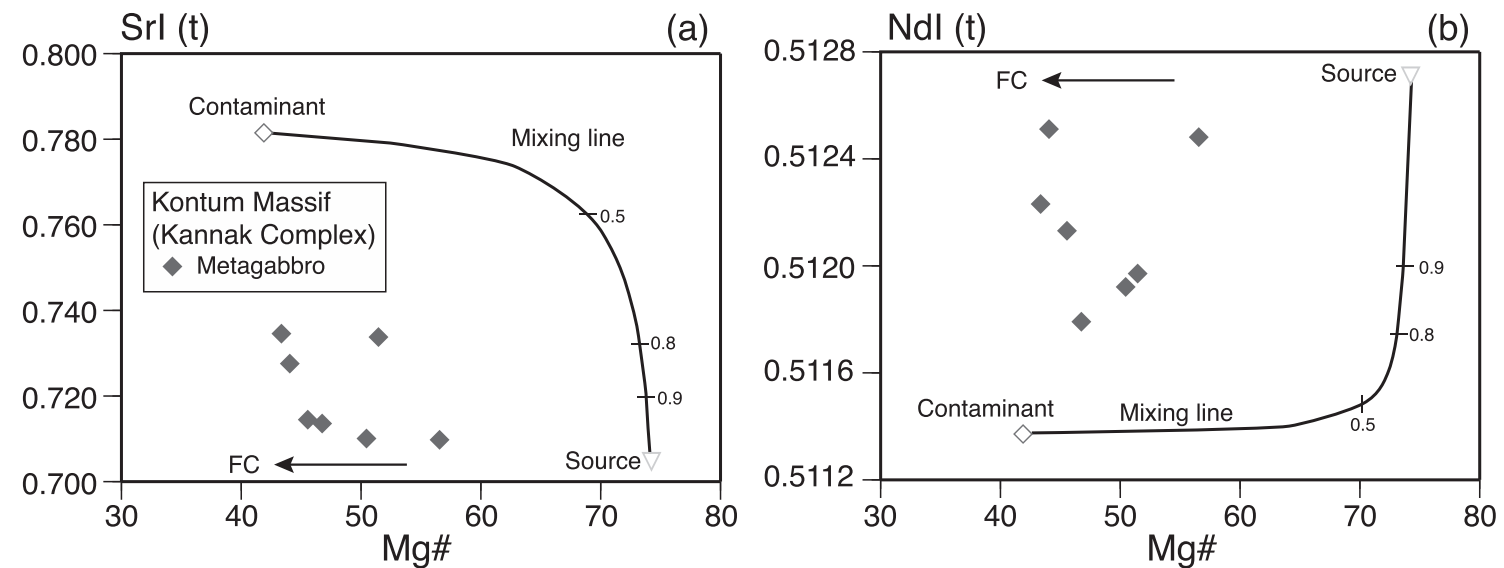

Figure 10. (a) Mg\#-SrI(t) and (b) Mg\#-NdI(t) diagrams with mixing lines. Ticks with numbers on the mixing lines indicate mixing proportions. End members for the source and contaminant are represented by a typical Song Da mafic rock (Wang et al., 2007) and pelitic gneiss (Lan et al., 2003), respectively. Fractional crystallization (FC) trend is shown by an arrow. Data for each end member are as follows: $\mathrm{Sr}=$ $102 \mathrm{ppm}, \mathrm{Nd}=4.4 \mathrm{ppm}, \mathrm{SrI}=0.7041, \mathrm{NdI}=0.51270, \mathrm{FeO}^{\text {(total) }}=10.2 \mathrm{wt} \%$, and $\mathrm{MgO}=16.1$ (source), and $\mathrm{Sr}=237 \mathrm{ppm}, \mathrm{Nd}=44.7 \mathrm{ppm}$, $\mathrm{SrI}=0.7814, \mathrm{NdI}=0.51137, \mathrm{FeO}^{\text {(total) }}=2.5 \mathrm{wt} \%$, and $\mathrm{MgO}=1.0$ (contaminant). Color version is available online from http://doi.org/ $10.2465 /$ jmps. $151019 \mathrm{~b}$.

of the Song Da igneous suite in order to evaluate the extent of crustal assimilation. The metagabbros lie between the $\mathrm{Nb} / \mathrm{La}$ values of primitive mantle and upper crust, and show a weak, positive correlation. Two samples (00041903B and 00041910B1) with high-LREE/ HREE ratios and negative $\mathrm{Ta}, \mathrm{Nb}$, and $\mathrm{Ti}$ anomalies (Fig. 7) possess $\varepsilon \mathrm{Nd}(t)$ values of -9.9 and -7.4 , respectively (Table 2), suggesting that these samples were assimilated by significant amounts of crustal materials during magma emplacement.

Some metagabbros (00041907E and 00041907C) possess high $\varepsilon \operatorname{Sr}(t)$ values (330 and 430$), \varepsilon \operatorname{Nd}(t)$ values of 4.1 and -1.4 (Table 2), and low Sr contents of 45-69 ppm (Table 2). These metagabbros would have been easily affected by the $\mathrm{Sr}$ isotopic ratios of crustal materials, as the host gneisses in the Kannak Complex have high $\mathrm{Sr}$ contents $(>200 \mathrm{ppm})$ and SrI ratios from 0.7258 to 0.7867 (Lan et al., 2003; Owada et al., 2007). Therefore, we conclude that most of metagabbros analyzed in this study have been isotopically modified by the host gneisses to some degree. The metagabbros possess evolved compositions with $\mathrm{Mg} \#$ from 40 to 60 (Fig. 10). In this 

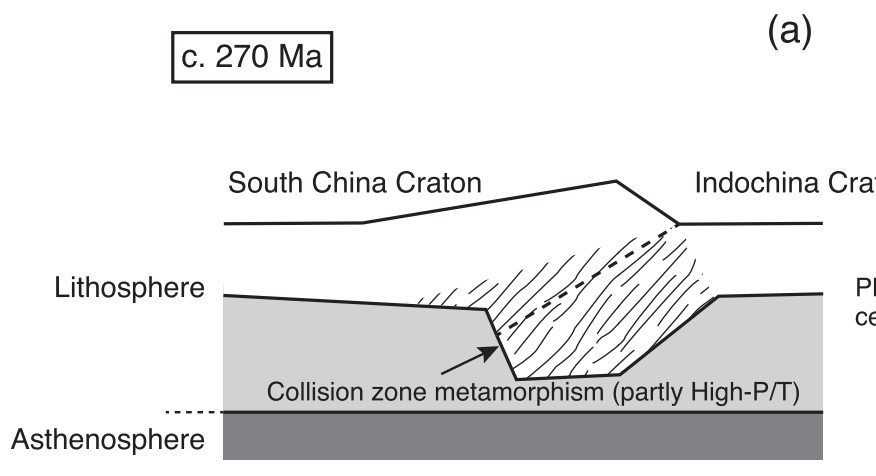

$$
\text { 260-250 Ma }
$$

(b)

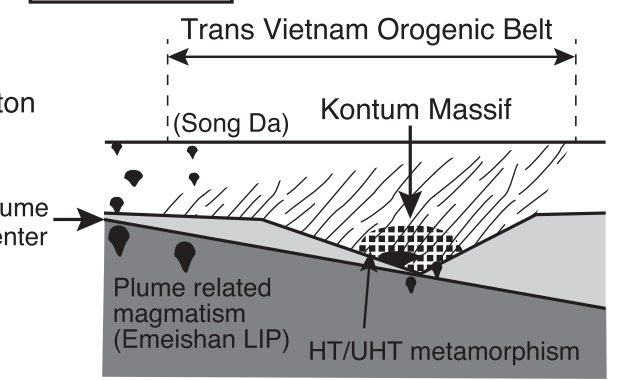

Figure 11. Schematic tectonic model for the evolution of the TVOB. (a) Continent-continent collision at $\sim 270$ Ma and (b) Late Permian plume-related magmatism at 260-250 Ma. The metagabbro described in this work formed in conjunction with the Song Da igneous suite as a result of plume-related magmatism. See text for discussion. Color version is available online from http://doi.org/10.2465/jmps.151019b.

figure, mixing lines plotted between a source (the most depleted Song Da mafic rock) and a contaminant (the most enriched host gneiss) indicate that the $\mathrm{Sr}$ and $\mathrm{Nd}$ isotopic values of the Kontum Massif metagabbros can be produced by crustal assimilation of less than $20 \%$ of the host gneiss (Figs. 10a and 10b). The zircon U-Pb ages and geochemical signatures obtained in this work therefore suggest that the metagabbro would have been originally derived from plume-related Song Da-type mafic magma, and was subsequently affected by crustal assimilation and fractional crystallization.

The Song Da igneous suite formed in the marginal part of the Emeishan plume (Hanski et al., 2010; He et al., 2010). The geochemistry and melting depth of the Emeishan LIP mafic magmas suggest that the lithospheric lid of the Emeishan plume was thicker at its periphery than at its head (fig. 12 in He et al., 2010). As such, a schematic model of Late Permian magmatism in the Kontum Massif can be constructed (Fig. 11). At $\sim 270$ $\mathrm{Ma}$, the Indochina craton was subducted beneath the South China craton (Osanai et al., 2008) whereby its crust was metamorphosed at high $P-T$ conditions (Fig. 11a). The Emeishan plume ascended through the asthenospheric mantle and formed the Emeishan LIP at 260-250 Ma. The plume-lithosphere boundary was likely inclined away from the plume center towards its margins (Fig. 11b). The base of thickened crust beneath the Kontum Massif was situated close to the plume-lithosphere boundary (Fig. 11b). As a result, plume-related magma intruded into the deeper part of the massif and induced HT/UHT metamorphism and crustal melting during the Late Permian (260-250 Ma).

\section{CONCLUDING REMARKS}

1) Zircon $\mathrm{U}-\mathrm{Pb}$ dating of charnockite from the Kannak Complex has revealed that its magma source may have formed as early as $\sim 1400 \mathrm{Ma}$, and it has since experienced two distinct high-grade metamorphic events during the Ordovician-Silurian and Permian periods. Furthermore, $\varepsilon \mathrm{Nd}$ values of pelitic gneisses and granitic rocks in the region suggest that the Kontum Massif could have formed from reworked continental crust.

2) Zircon U-Pb dating of metagabbro produced magmatic ages of 260-250 Ma that are identical to those reported for peak metamorphic periods in the Kontum Massif. Mantle-derived magma is interpreted to have played an important role as a heat source for HT/UHT metamorphism and partial melting of the massif crust.

3) The geochemical and geochronological signatures of Kontum Massif metagabbros are almost identical to those of plume-related basalts in the Song Da igneous suite, which were originally derived from the Emeishan mantle plume and were affected by crustal assimilation. Plume-related magmas intruded into the Kontum Massif lower crust were associated with HT/UHT metamorphism and crustal anatexis, and experienced various amounts of crustal assimilation during the Late Permian (260-250 Ma).

\section{ACKNOWLEDGMENTS}

We wish to thank Tran Ngoc Nam, Trinh Van Long and Pham Binh for helpful discussion and advice during the fieldwork. Thanks go to H. Kawabata and an anonymous reviewer for the critical comments of the manuscript. We also thank Satish-Kumar for useful comments and editorial handling. This work was supported by Kakenhi (Grant-in-Aid for Scientific Research) provided by Japan Society for the Promotion of Science (15H03748, M. Owada; 22244063, Y. Osanai). 


\section{SUPPLEMENTARY MATERIAL}

Supplementary Table S1 and color version of all Figures are available online from http://doi.org/10.2465/jmps. $151019 \mathrm{~b}$

\section{REFERENCES}

Adachi, T., Osanai, Y., Nakano, N. and Owada, M. (2012) LAICP-MS U-Pb zircon and FE-EPMA U-Th-Pb monazite datings on pelitic granulites from the Mt. Uki-dake area, Sefuri Mountains, northern Kyushu. Journal of Geological Society of Japan, 118, 39-52.

Ali, J.R., Thompson, G.M., Zhou, M.F. and Song, X.Y. (2005) Emeishan large igneous province, SW China. Lithos, 79, 475-489.

Black, L.P., Kamo, S.L., Allen, C.M., Aleinikoff, J.N., Davis, D.W., Korsch, R.J. and Foudoulis, C. (2003) TEMORA 1: a new zircon standard for Phanerozoic U-Pb geochronology. Chemical Geology, 200, 155-170.

Carter, A., Roques, D., Bristow, C. and Kinny, P. (2001) Understanding Mesozoic accretion in Southeast Asia: Significance of Triassic thermotectonism (Indosinian orogeny) in Vietnam. Geology, 29, 211-214.

Chung, S.L. and Jahn, B.M. (1995) Plume-lithosphere interaction in generation of the Emeishan flood basalts at the Permo-Triassic boundary. Geology, 23, 889-892.

Condie, K.C. (1997) Plate Tectonics and Crustal Evolution $4^{\text {th }}$ Edition. pp. 282, Butterworth-Heinemann, Oxford.

Griffin, W.L., Powell, W.J., Pearson, N.J. and O'Reilly, S.Y. (2008) Appendix 2. GLITTER: data reduction software for laser ablation ICP-MS. In Laser ablation-IP-MS in the earth sciences (Sylvester, P. Ed.). Mineralogical Association of Canada, Short Course Series 40, 204-207.

Hanski, E., Walker, R.J., Huhma, H., Polyakov, G.V., Balykin, P., Tran Trong Hoa and Ngo Thi Phuong (2004) Origin of the Permian-Triassic komatiites, northwestern Vietnam. Contributions to Mineralogy and Petrology, 147, 453-469.

Hanski, E., Kamenetsky, V.S., Luo, Z.Y., Xu, Y.G. and Kuzmin, D.V. (2010) Primitive magmas in the Emeishan Large Igneous Province, southwestern China and northern Vietnam. Lithos, 119, 75-90.

He, Q., Xiao, L., Balta, B., Gao, R. and Chen, J. (2010) Variety and complexity of the Late-Permian Emeishan basalts: Reappraisal of plume-lithosphere interaction processes. Lithos, 119, 91107

Hibbard, M. J. (1995) Petrography to Petrogenesis. pp. 587, Prentice Hall, New Jersey.

Hutchison, C.S. (1989) Geological Evolution of Southeast Asia. pp. 368, Oxford Monograph on Geology and Geophysics, 13.

Ishiwatari, A. and Tsujimori, T. (2003) Paleozoic ophiolites and blueschists in Japan and Russian Primorye in the tectonic framework of East Asia: A synthesis. Island Arc, 12, 190206.

Jackson, S.E., Pearson, N.J., Griffin, W.L. and Belousova, E.A. (2004) The application of laser ablation-inductively coupled plasma mass spectrometry to in situ U-Pb zircon geochronology. Chemical Geology, 211, 47-69.

Kagami, H., Iwata, M., Sano, S. and Honma, H. (1987) Sr and Nd isotopic compositions and $\mathrm{Rb}, \mathrm{Sr}, \mathrm{Sm}$ and $\mathrm{Nd}$ concentrations of standard samples. Technical Report, Institute for Study of the Earth's Interior, Okayama University, Ser. 4, 1-16.

Lan, Y.L., Chung, S.L., Trinh Van Long, Lo, C.H., Lee, T.Y., Mertzman, S.A. and Shen, J.J.S. (2003) Geochemical and $\mathrm{Sr}-\mathrm{Nd}$ isotopic constraints from the Kontum massif, central Vietnam on the crustal evolution of the Indochina block. Precambrian Research, 122, 7-27.

Lepvrier, C., Nguyen Van Vuong, Malski, H., Phan Truong Thi and Vu Van Tich (2008) Indosinian tectonics in Vietnam. Computes Rendus Geoscience, 340, 91-111.

Ludwig K.R. (2008) Isoplot 3.6: a geochronological toolkit for Microsoft Excel, pp. 77, Berkeley Geochronology Center Special Publication, Berkeley, 4.

Lugmair, G.W. and Marti, K. (1978) Lunar initial ${ }^{143} \mathrm{Nd} /{ }^{144} \mathrm{Nd}$ : differential evolution of the Lunar crust and mantle. Earth and Planetary Science Letters, 39, 349-357.

Maluski, H., Lepvrier, C., Keyreloup, A., Vu Van Tich and Phan Truong Thi (2005) ${ }^{40} \mathrm{Ar}^{-39} \mathrm{Ar}$ geochronology of the charnokites and granulites of the Kan Nack complex, Kon Tum Massif, Vietnam. Journal of Asian Earth Sciences, 25, 653-677.

McDonough, W.F. and Sun, S.S. (1995) The composition of the earth. Chemical Geology, 120, 223-253.

Metcalfe, I. (1999) Gondwana dispersion and Asian accretion: An overview. In Gondwana Dispersion and Asian Accretion (Metcalfe, I. Ed.). Balkema, Rotterdam, Holland, 9-28.

Miyashiro, A. (1978) Nature of alkalic volcanic rock series. Contributions to Mineralogy and Petrology, 66, 91-104.

Nagy, E.A., Maluski, H., Lepvrier, C., Schärer, U., Phan Truong Thi, Leyreloup, A. and Vu Van Thich (2001) Geodynamic significance of the Kontum massif in central Vietnam. Composite ${ }^{40} \mathrm{Ar} /{ }^{39} \mathrm{Ar}$ and $\mathrm{U}-\mathrm{Pb}$ ages from Paleozoic to Triassic. Journal of Geology, 109, 755-770.

Nakano, N., Osanai, Y., Owada, M., Tran Ngoc Nam, Tsunogae, T., Toyoshima, T. and Pham Binh (2004) Decompression process of mafic granulite from eclogite to granulite facies under ultrahigh-temperature condition in the Kontum Massif, central Vietnam. Journal of Mineralogical and Petrological Sciences, 99, 242-256.

Nakano, N., Osanai, Y. and Owada, M. (2007a) Multiple breakdown and chemical equilibrium of silisic clinopyroxene under extreme metamorphic conditions in the Kontum Massif, central Vietnam. American Mineralogist, 92, 1844-1855.

Nakano, N., Osanai, Y., Owada, M., Tran Ngoc Nam, Toyoshima, T., Pham Binh, Tsunogae, T. and Kagami, H. (2007b) Geologic and metamorphic evolutions of the basement complexes in the Kontum Massif, central Vietnam. Gondwana Research, $12,438-453$.

Nakano, N., Osanai, Y., Nguyen Thi Minh, Miyamoto, T., Hayasaka, Y. and Owada, M. (2008) Discovery of high-pressure granulite-facies metamorphism in northern Vietnam: constrains on Permo-Triassic Indochines continental collision tectonics. Comptes Rendux Geoscience, 340, 127-138.

Nakano, N., Osanai, Y., Owada, M., Hayasaka, Y. and Tran Ngoc Nam (2009) Permo-Triassic Barrovian-type metamorphism in the ultrahigh-temperature Kontum Massif, central Vietnam: constraints on continental collision tectonics in Southeast Asia. Island Arc, 18, 126-143.

Nakano, N., Osanai, Y., Sajeev, K., Hayasaka, Y., Miyamoto, T., Nguyen Thi Minh, Owada, M. and Windley, B. (2010) Triassic eclogite from northern Vietnam: inferences and geological significance. Journal of Metamorphic Geology, 28, 59-76.

Nakano, N., Osanai, Y., Owada, M., Tran Ngoc Nam, Charusiri, P. and Khamphavong, K. (2013) Tectonic evolution of high- 
grade metamorphic terranes in central Vietnam: Constrains from large-scale monazite geochronology. Journal of Asian Earth Sciences, 73, 520-539.

Nakano, N., Osanai, Y., Satish-Kumar, M., Adachi, T., Owada, M., Jargalan, S., Boldbaatar, C., Yoshimoto, A. and Syeryekhan, K. (2014) Paleozoic subduction - accretion - closure histories in the west Mongolian segment of the Paleo-Asian Ocean: Evidence from pressure - temperature - time - protolith evolution of high- $\mathrm{Mg}$ and $-\mathrm{Al}$ gneisses in the Altai Mountains. Journal of Geology, 122, 283-308.

Oh, C.W., Kim, S.W, Choi, S.G., Zhai, M., Guo, J. and Sajeev, K. (2005) First finding of eclogite facies metamorphic event in South Korea and its correlation with the Dabie - Sulu collision belt in China. Journal of Geology, 113, 226-232.

Okay, A.I., Sengor, A.M.C. and Satir, M. (1989) Tectonics of an ultrahigh-pressure metamorphic terrane: the Dabie Shan/ Tongbai Shan Orogen, China. Tectonics, 12, 1320-1334.

Osanai, Y., Nakano, N., Owada, M., Tran Ngoc Nam, Toyoshima, T., Tsunogae, T. and Pham Binh (2004) Permo-Triassic ultrahigh-temperature metamorphism in the Kontum Massif, central Vietnam. Journal of Mineralogical and Petrological Sciences, 99, 225-241.

Osanai, Y., Nakano, N., Owada, M., Tran Ngoc Nam, Miyamoto, T., Nguyen Thi Minh, Nguyen Van Nam and Tran Van Tri (2008) Collision zone metamorphism in Vietnam and adjacent South-eastern Asia: Proposition for Trans Vietnam Orogenic Belt. Journal of Mineralogical and Petrological Sciences, 103, 226-241.

Owada, M., Osanai, Y., Hokada, T. and Nakano, N. (2006) Timing of metamorphism and formation of garnet granite in the Kontum Massif, central Vietnam: Evidence from monazite EMP dating. Journal of Mineralogical and Petrological Sciences, $101,324-328$.

Owada, M., Osanai, Y., Nakano, N., Matsushita, T., Tran Ngoc Nam, Tsunogae, T., Toyoshima, T., Pham Binh and Kagami, H. (2007) Crustal anatexis and formation of two types of granitic magmas in the Kontum Massif, central Vietnam: Implications for magma processes in collision zones. Gondwana Research, 12, 428-437.

Paces, J.B. and Miller, J.D.J. (1993) U-Pb ages of Duluth Complex and relate mafic intrusions, norutheastern Minnesota: geochronological insights to physical, petrogenetic, paleomagnetic, and tectonomagmatic processes associated with the $1.1 \mathrm{Ga}$ midcontinent rift system. Journal of Geophysical Research, 98, 13997-14013.

Peate, D.W. (1997) Parana-Etendeka province. In Large Igneous Province: Continental, Oceanic, and Planetary Flood Volcanism (Mahoney, J.J. and Coffin, M.E. Eds.). American Geophysical Union, Geophysical Monograph Series, 100, 217245.

Ree, J.H., Cho, M., Kwon, S.T. and Nakamura, E. (1996) Possible eastward extension of Chinese collision belt in South Korea: the Imjingang belt. Geology, 24, 1071-1074.

Roger, F., Maluski, H., Leyreloup, A., Lepvrier, C. and Phan Tuong Thi (2007) U-Pb dating of high temperature metamorphic episodes in the Kon Tum Massif (Vietnam). Journal of Asian Earth Sciences, 30, 565-572.

Rudnick, R.L. and Gao, S. (2003) Composition of the continental crust. In The Crust (Rudnic, R.L. Ed.). Treatise in Geochemistry, 3, 1-64.

Shellnutt, J.G. (2014) The Emeishan large igneous province: A synthesis. Geoscience Frontiers, 5, 369-394.
Steiger, R.H. and Jäger, E. (1977) Subcommision of geochronology: convention on the use of decay constants in geo- and cosmochronology. Earth and Planetary Science Letters, 36, 359-362.

Sun, S.-s. and McDonough, W.F. (1989) Chemical and isotopic systematics of oceanic basalts: implications for mantle composition and processes. Geological Society of London Special publication, 42, 313-345.

Tanaka, T., Togashi, S., Kamioka, H., Amakawa, H., Kagami, H., Hamamoto, T., Yuhara, M., Orihashi, Y., Yoneda, S., Shimizu, H., Kunimaru, T., Takahashi, K., Yanagi, T., Nakano, T, Fujimaki, H., Shinjo, R., Asahara, Y., Tanimizu, M. and Dragusanu, C. (2000) JNdi-1: a neodymium isotopic reference in consistency with LaJolla neodymium. Chemical Geology, $168,279-281$.

Tran Ngoc Nam, Sano, Y., Terada, K., Toriumi, M., Phan Van Quynh and Le Eien Dung (2001) First SHRIMP U-Pb zircon dating of granulites from the Kontum massif (Vietnam) and tectonothermal implications. Journal of Asian Earth Sciences, $19,77-84$.

Tran Quoc Hai (1986) The evolution of magmatism and metamorphism in Precambrian of Vietnam's territory. Proceedings of 1st Conference for Geology of Indochina, 1, 201-207.

Tran Viet Anh, Pang, K.N., Chung, S.L., Lin, H.M., Tran Trong Hoa, Tran Tuan Anh and Yang, H.J. (2011) The Song Da magmatic suite revisited: A petrologic, geochemical and $\mathrm{Sr}-$ $\mathrm{Nd}$ isotopic study on picrites, flood basalts and silisic volcanic rocks. Journal Asian Earth Sciences, 42, 1341-1355.

United Nations (1990) Atlas of mineral resources of the ESCAP region, 6, Vietnam, pp. 124, United Nations Publication, Bangkok.

Usuki, T., Lan, C.Y., Yui, T.F., Iizuka, Y., Van Tich Vu, Tuan Anh Tran, Okamoto, K., Wooden, J.L. and Liou, J.G. (2009) Early Paleozoic medium-pressure metamorphism in central Vietnam: evidence from SHRIMP U-Pb zircon ages. Geoscience Journal, 13, 245-256.

Usuki, T., Lan, C.Y., Trong Hoa Tran, Dung Pham, Wang, K.L., Shellnutt, G.J. and Chung, S.L. (2015) Zircon U-Pb ages and $\mathrm{Hf}$ isotopic compositions of alkaline silisic magmatic rocks in the Phan Si Pan - Tu Le region, northern Vietnam: Identification of a displaced western extension of the Emeishan Large Igneous Province. Journal of Asian Earth Sciences, 97, 102124.

Vladimirov, A.G., Balykin, P.A, Phan Luu Anh, Kruk, N.N., Ngo Thi Phuong, Travin, A.V., Tran Trong Hoa, Annikova, I.Yu., Kuybida, M.L., Borodina, E.V., Karmysheva, I.V. and Bui An Nien (2012) The Khao Que - Tam Tao gabbro-granite Massif, northern Vietnam: A petrological indicator of the Emeishan Plume. Russian Journal of Pacific Geology, 6, 395-411.

Wang, C.Y., Zhou, M.F and Qi, L. (2007) Permian flood basalts and mafic intursions in the Jinping (SW China) - Song Da (northern Vienam) district: Mantle sources, crustal contamination and sulfide segregation. Chemical Geology, 243, 317343.

Winchester, J.A. and Floyd, P.A. (1977) Ceochemical discrimination of different magma series and their differentiation products using immobile elements. Chemical Geology, 20, 325343.

Xiao, L., Xu, Y.G., Mei, H.J., Zheng, Y.F., He, B. and Pirajno, F. (2004) Distinct mantle sources of low-Ti and High-Ti basalts from the western Emeishan large igneous province, SW China: implications for plume-lithosphere interaction. Earth and 
Planetary Science Letters, 228, 525-546.

Xu, Y., Chung, S.L., Jahn, B.M. and Wu, G. (2001) Petrologic and geochemical constraints on the petrogenesisi of Permian-Triassic Emeishan flood basalts in southwestern China. Lithos, $58,145-168$.

Yamasaki, T., Owada, M., Imaoka, T. and Shiraki, K. (1999) Major and trace element analyses of rock samples by X-ray fluorescence spectrometry. Report of the Center for Instrumental Analyses, Yamaguchi University, No. 7, 22-31.
Zhang, R.Y., Liou, J.G and Tsai, C.H. (1996) Petrogenesis of a high-temperature metamorphic terrane: a new tectonic interpretation for the north Dabieshan, central China. Journal of Metamorphic Geology, 14, 319-333.

Manuscript received October 19, 2015

Manuscript accepted May 5, 2016

Published online June 24, 2016

Manuceript handled by M. Satish-Kumar 